\title{
Halorubrum aquaticum sp. nov., an archaeon isolated from hypersaline lakes
}

Correspondence

M. C. Gutiérrez

mcg@us.es

\author{
M. C. Gutiérrez, ${ }^{1}$ A. M. Castillo, ${ }^{1}$ P. Corral, ${ }^{1}$ M. Kamekura ${ }^{2}$ and A. Ventosa ${ }^{1}$ \\ 1'Department of Microbiology and Parasitology, Faculty of Pharmacy, University of Sevilla, 41012 \\ Sevilla, Spain \\ ${ }^{2}$ Halophiles Research Institute, 677-1 Shimizu, Noda-shi, Chiba-ken 278-0043, Japan
}

Members of the family Halobacteriaceae, the single recognized family within the order Halobacteriales, have long been known as the most abundant micro-organisms in hypersaline environments (Oren, 1994). At the time of writing, the family Halobacteriaceae comprises 27 genera (Oren et al., 2009). The genus Halorubrum was established by McGenity \& Grant (1995) and currently contains 23 species: four haloalkaliphilic species, Halorubrum vacuolatum (Kamekura et al., 1997), Hrr. tibetense (Fan et al., 2004), Hrr. alkaliphilum (Feng et al., 2005) and Hrr. luteum ( $\mathrm{Hu}$ et al., 2008), and 19 neutrophilic species, Hrr. trapanicum (Petter, 1931), Hrr. saccharovorum (Tomlinson \& Hochstein, 1976), Hrr. sodomense (Oren, 1983), Hrr. distributum (Oren \& Ventosa, 1996), Hrr. lacusprofundi (Franzmann et al., 1988), Hrr. coriense (Kamekura \& Dyall-Smith, 1995; McGenity \& Grant, 1995), Hrr. tebenquichense (Lizama et al., 2002), Hrr. terrestre (Ventosa et al., 2004), Hrr. xinjiangense (Feng et al., 2004), Hrr. ezzemoulense (Kharroub et al., 2006), Hrr. lipolyticum and Hrr. aidingense (Cui et al., 2006), Hrr. orientale (Castillo et al., 2006), Hrr. arcis (Xu et al., 2007),

The GenBank/EMBL/DDBJ accession number for the 16S rRNA gene sequence of strain $\mathrm{EN}-2^{\top}$ is $\mathrm{AM} 268115$.

Two supplementary figures are available with the online version of this paper.
Hrr. litoreum (Cui et al., 2007), Hrr. ejinorense (Castillo et al., 2007), Hrr. kocurii (Gutiérrez et al., 2008), Hrr. californiense (Pesenti et al., 2008) and Hrr. cibi (Roh \& Bae, 2009).

In the present study, we characterized two strains, $\mathrm{EN}-2^{\mathrm{T}}$ and $\mathrm{SH}-4$, which were isolated from water samples of the saline lakes Erliannor $\left(43^{\circ} 44^{\prime} \mathrm{N} 112^{\circ} 02^{\prime} \mathrm{E}\right)$ and Shangmatala $\left(43^{\circ} 12^{\prime} \mathrm{N} 114^{\circ} 01^{\prime} \mathrm{E}\right)$, respectively, located in the Inner Mongolia Autonomous Region, China. At the time of sampling, the temperatures and $\mathrm{pH}$ of the lakes were $18.4{ }^{\circ} \mathrm{C}$ and $19.8{ }^{\circ} \mathrm{C}$ and $\mathrm{pH} 7.5$ and 8.0, respectively. Water samples were plated on agar plates of halophilic medium (MH), containing (per litre distilled water) $195 \mathrm{~g}$ $\mathrm{NaCl}, 32.5 \mathrm{~g} \mathrm{MgCl}_{2} .6 \mathrm{H}_{2} \mathrm{O}$, $50.8 \mathrm{~g} \mathrm{MgSO}_{4} .7 \mathrm{H}_{2} \mathrm{O}, 0.8 \mathrm{~g}$ $\mathrm{CaCl}_{2}, 5 \mathrm{~g} \mathrm{KCl}, 0.16 \mathrm{~g} \mathrm{NaHCO}_{3}, 0.6 \mathrm{~g} \mathrm{NaBr}, 5 \mathrm{~g}$ yeast extract and $20 \mathrm{~g}$ agar ( $\mathrm{pH} \mathrm{7.5)}$, and incubated at $37^{\circ} \mathrm{C}$ for 1-2 weeks. Pure culture was obtained by repeated subcultivation on the same medium.

For comparative purposes, the following strains were obtained from the Japan Collection of Microorganisms (JCM) and the Spanish Type Culture Collection (CECT): Hrr. cibi JCM $15757^{\mathrm{T}}$, Hrr. alkaliphilum JCM $12358^{\mathrm{T}}$, Hrr. lipolyticum 9-3 $3^{\mathrm{T}}$, Hrr. luteum CECT $7303^{\mathrm{T}}$, Hrr. kocurii JCM $14978^{\mathrm{T}}$ and Hrr. tibetense JCM $11889^{\mathrm{T}}$. The Hrr. cibi, 
Hrr. kocurii and Hrr. lipolyticum strains were routinely cultivated on JCM medium no. 168, Hrr. tibetense JCM $11889^{\mathrm{T}}$ and Hrr. alkaliphilum JCM $12358^{\mathrm{T}}$ were cultivated on JCM medium no. 167 and Hrr. luteum CECT $7303^{\mathrm{T}}$ was cultivated on CECT medium no. 248.

Phenotypic tests were performed according to the proposed minimal standards for the description of new taxa of the order Halobacteriales (Oren et al., 1997). Motility and morphology of cells from exponentially growing liquid cultures were examined using an Olympus BX41 microscope equipped with phase-contrast optics. Cells of strains EN-2 ${ }^{\mathrm{T}}$ and SH-4 were motile rods (Supplementary Fig. S1, available in IJSEM Online). Colony morphology, colour and size were observed by growth on $\mathrm{MH}$ agar after incubation at $37^{\circ} \mathrm{C}$ for 10 days. Growth with $0,0.5,1,3,5$, $7,10,15,20,25$ and $30 \%(\mathrm{w} / \mathrm{v}) \mathrm{NaCl}$ was determined on $\mathrm{MH}$ agar. Growth at $\mathrm{pH} 5.0-11.0$ (at intervals of $0.5 \mathrm{pH}$ unit) was determined in liquid $\mathrm{MH}$ with the $\mathrm{pH}$ readjusted after sterilization and growth was assessed by measuring the optical density at $600 \mathrm{~nm}$. The temperature range for growth was assessed on $\mathrm{MH}$ agar at $15-55{ }^{\circ} \mathrm{C}$ (at intervals of $5{ }^{\circ} \mathrm{C}$ ). Tests for catalase and oxidase, hydrolysis of starch, Tween 80, gelatin, casein, DNA and aesculin, reduction of nitrate and nitrite, formation of $\mathrm{H}_{2} \mathrm{~S}$ and indole and utilization of sugars, alcohols, amino acids and organic acids were carried out as described by Oren et al. (1997). Susceptibility to antibiotics was determined on MH agar using antibiotic discs containing ( $\mu$ g per disc unless otherwise stated): ampicillin (10) bacitracin (10 U), chloramphenicol (30), erythromycin (15), nalidixic acid (30), neomycin (30), novobiocin (30), rifampicin (5) and streptomycin (10). The physiological and biochemical characteristics as well as the antibiotic susceptibilities of strains $\mathrm{EN}-2^{\mathrm{T}}$ and $\mathrm{SH}-4$ are provided in the species description and Table 1.

Polar lipids of both isolates were extracted with chloroform/methanol as described previously (Kamekura, 1993) and separated by TLC using Merck HPTLC silica gel 60 plates (no. 5641) and chloroform/methanol/acetic acid/water $(85: 22.5: 10: 4$, by vol.). Glycolipids were detected as purple spots by spraying with $0.5 \% \alpha$-naphthol in methanol/water $(1: 1)$ and then with sulfuric acid/ ethanol $(1: 1)$, followed by heating at $160{ }^{\circ} \mathrm{C}$. The polar lipid profiles of the isolates and the reference strains are shown in Supplementary Fig. S2. Strains $\mathrm{EN}-2^{\mathrm{T}}$ and $\mathrm{SH}-4$ contained phosphatidylglycerol, phosphatidylglycerol phosphate methyl ester, sulfated diglycosyl diethers and several unidentified glycolipids. Phosphatidylglycerol sulfate was not detected. This polar lipid profile is typical of neutrophilic species of the genus Halorubrum (McGenity \& Grant, 2001).

Chromosomal DNA of strains $\mathrm{EN}-2^{\mathrm{T}}$ and $\mathrm{SH}-4$ was isolated and purified according to the method described by Marmur (1961). The G $+C$ content of genomic DNA was determined from the mid-point $\left(T_{\mathrm{m}}\right)$ of the thermal denaturation profile (Marmur \& Doty, 1962) using the
Table 1. Characters that differentiate Halorubrum aquaticum sp. nov. from other closely related species of the genus Halorubrum

Strains: 1, Halorubrum aquaticum sp. nov. EN-2 ${ }^{\mathrm{T}}$ and SH-4; 2, Hrr. cibi JCM $15757^{\mathrm{T}}$; 3 , Hrr. tibetense JCM $11889^{\mathrm{T}}$ (data for columns 1-3 from this study); 4, Hrr. alkaliphilum JCM $12358^{\mathrm{T}}$ (data from Feng et al., 2005 unless otherwise stated); 5, Hrr. luteum CECT $7303^{\mathrm{T}}$ (Hu et al., 2008); 6, Hrr. lipolyticum JCM $13559^{\mathrm{T}}$ (Cui et al., 2006); 7, Hrr. saccharovorum JCM 8865 ${ }^{\mathrm{T}}$ (Tomlinson \& Hochstein, 1976); 8, Hrr. kocurii JCM $14978^{\mathrm{T}}$ (this study). +, Positive; -, negative; ND, no data available.

\begin{tabular}{|c|c|c|c|c|c|c|c|c|}
\hline Characteristic & 1 & 2 & 3 & 4 & 5 & 6 & 7 & 8 \\
\hline Cell morphology & RO & RO & RO & SR & PL & RO & RO & Ro \\
\hline Motility & - & + & - & $+\dagger$ & + & + & + & - \\
\hline Colony colour & $\mathrm{RE}$ & RE & RE & $\mathrm{PK} \dagger$ & $\mathrm{O}$ & $\mathrm{RE}$ & PK & RE \\
\hline $\mathrm{Mg}^{2+}$ requirement & - & + & - & - & - & + & + & - \\
\hline Nitrate reduction & + & - & + & $+\dagger$ & + & + & + & + \\
\hline Indole production & - & - & + & + & + & - & + & - \\
\hline Oxidase & - & - & + & + & + & + & + & + \\
\hline Starch hydrolysis & - & - & - & - & - & + & - & - \\
\hline Tween 80 hydrolysis & + & - & + & - & - & + & - & - \\
\hline Gelatin liquefaction & - & - & - & - & - & + & - & - \\
\hline \multicolumn{9}{|l|}{ Utilization of: } \\
\hline D-Fructose & + & - & - & + & - & + & - & - \\
\hline D-Glucose & + & - & + & + & + & + & + & - \\
\hline Lactose & + & + & + & - & + & - & + & - \\
\hline D-Mannitol & - & - & + & - & - & - & - & - \\
\hline Sucrose & + & - & + & - & - & + & + & - \\
\hline Succinate & - & - & + & - & + & - & + & - \\
\hline $\begin{array}{r}\text { Presence of } \\
\text { glycolipids }\end{array}$ & + & + & - & - & - & + & - & + \\
\hline \multicolumn{9}{|l|}{$\begin{array}{l}\text { Sensitivity to } \\
\text { (per disc): }\end{array}$} \\
\hline Bacitracin $(10 \mathrm{U})$ & + & + & - & - & - & + & $\mathrm{ND}$ & + \\
\hline $\begin{array}{l}\text { Erythromycin } \\
(15 \mu \mathrm{g})\end{array}$ & - & - & - & $\mathrm{ND}$ & + & - & + & - \\
\hline $\begin{array}{l}\text { Rifampicin } \\
(5 \mu \mathrm{g})\end{array}$ & - & - & - & - & - & + & ND & + \\
\hline $\begin{array}{l}\text { DNA G }+\mathrm{C} \\
\text { content }(\mathrm{mol} \%)\end{array}$ & 62.1 & 61.7 & 63.3 & 62.1 & 60.2 & 65.9 & 60.9 & 61.2 \\
\hline
\end{tabular}

${ }^{*}$ PL, Pleomorphic; RO, rods; SR, short rods.

$\dagger$ Data obtained in this study.

‡O, Orange; PK, pink; RE, red.

equation of Owen \& Hill (1979) as described previously (Ventosa et al., 2004). The DNA G + C content of strains $\mathrm{EN}-2^{\mathrm{T}}$ and $\mathrm{SH}-4$ was $62.1 \mathrm{~mol} \%$. This value is within the range described for the genus Halorubrum (60.0$71.2 \mathrm{~mol} \%$; Grant et al., 2001). The 16S rRNA genes of strains $\mathrm{EN}-2^{\mathrm{T}}$ and SH-4 were sequenced by PCR using universal primers as described elsewhere (López-García et al., 2001; Arahal et al., 1996). The almost-complete $16 \mathrm{~S}$ rRNA gene sequences of strains EN $-2^{\mathrm{T}}$ (1420 bp) and SH-4 (1381 bp) were determined. ARB software (Ludwig et al., 2004) was used for sequence analysis. Following the 
recommendations of Ludwig et al. (1998), phylogenetic trees were generated using alternative treeing methods (maximum parsimony, neighbour joining and maximum likelihood) (Saitou \& Nei, 1987). Base-frequency filters were applied in the sequence comparison analysis and the effects on the results were evaluated. The topologies of the neighbour-joining and maximum-likelihood trees were similar to that of the maximum-parsimony tree (not shown). The identification of phylogenetic neighbours and calculation of pairwise sequence similarity were achieved using the EzTaxon server (http://www.eztaxon.org/; Chun et al., 2007). The maximum-parsimony phylogenetic tree (Fig. 1) indicated that strains $\mathrm{EN}-2^{\mathrm{T}}$ and $\mathrm{SH}-4$ were closely related to Hrr. cibi $\mathrm{B} 31^{\mathrm{T}}$ (97.9 and $98.0 \%$ 16S rRNA gene sequence similarity, respectively), Hrr. tibetense $8 \mathrm{~W} 8^{\mathrm{T}}(97.3$ and $97.7 \%), H r$. alkaliphilum $\mathrm{DZ}-\mathrm{-}^{\mathrm{T}}$ (96.8 and $97.1 \%$ ), Hrr. luteum CGSA15 ${ }^{\mathrm{T}}$ (96.8 and 97.0\%) and Hrr. lipolyticum JCM $13559^{\mathrm{T}}$ (96.8 and 97.0\%).

DNA-DNA hybridization between strains $\mathrm{EN}-2^{\mathrm{T}}$ and $\mathrm{SH}-4$ and the phylogenetically most closely related type strains of species of the genus Halorubrum was performed by the competition procedure of Johnson (1994), as described in detail by Gutiérrez et al. (2002). DNA-DNA relatedness between strains $\mathrm{EN}-2^{\mathrm{T}}$ and $\mathrm{SH}-4$ was 98 and $95 \%$ (reciprocal hybridizations). These values showed that the two isolates can be considered to represent the same species (Stackebrandt et al., 2002). DNA-DNA relatedness between strains $\mathrm{EN}-2^{\mathrm{T}}$ and $\mathrm{SH}-4$ and Hrr. cibi JCM $15757^{\mathrm{T}}$, Hrr. tibetense JCM $11889^{\mathrm{T}}$, Hrr. alkaliphilum JCM $12358^{\mathrm{T}}$, Hrr. luteum CECT $7303^{\mathrm{T}}$ and Hrr. lipolyticum JCM $13559^{\mathrm{T}}$ was 38 and $27 \%, 45$ and $39 \%, 37$ and $43 \%$, 23 and $30 \%$ and 25 and $18 \%$, respectively. These levels of DNA-DNA relatedness are low enough to classify the two isolates in a genotypically distinct species within the genus Halorubrum.

Differences in phenotypic characteristics (such as motility, oxidase, reduction of nitrate and nitrite, hydrolysis of different compounds and utilization of several substrates) (Table 1), polar lipid profiles and 16S rRNA gene sequences, together with the DNA-DNA hybridization data, justify the creation of a novel species within the genus Halorubrum to accommodate strains $\mathrm{EN}-2^{\mathrm{T}}$ and SH-4 (Wayne et al., 1987; Stackebrandt \& Goebel, 1994). The name Halorubrum aquaticum sp. nov. is proposed.

\section{Description of Halorubrum aquaticum sp. nov.}

Halorubrum aquaticum (a.qua'ti.cum. L. neut. adj. aquaticum living, growing or found in or by water, aquatic).

Cells are rods $(1.0-1.2 \times 2.0-6.0 \mu \mathrm{m})$. Non-motile. Colonies are circular, entire, smooth, red and $0.5-1.5 \mathrm{~mm}$ in diameter on $\mathrm{MH}$ agar after 7 days at $37^{\circ} \mathrm{C}$. Growth occurs with $2.5-5.0 \mathrm{M} \mathrm{NaCl}$ (optimum $3.4 \mathrm{M} \mathrm{NaCl}$ ). $\mathrm{MgCl}_{2}$ is not required. Strict aerobe. Growth occurs at $25-50{ }^{\circ} \mathrm{C}$ (optimum $35-40{ }^{\circ} \mathrm{C}$ ) and $\mathrm{pH}$ 6.0-9.0 (optimum $\mathrm{pH}$ 7.5). Chemo-organotrophic. Oxidase-negative and catalase-positive. Nitrate and nitrite are reduced. Tween 80 , urea and aesculin are hydrolysed, but casein, DNA, starch and gelatin are not. $\mathrm{H}_{2} \mathrm{~S}$ is not produced. Indole is not produced from tryptophan. Methyl red and VogesProskauer tests are negative. Arginine dihydrolase, lysine decarboxylase and ornithine decarboxylase are not produced. Anaerobic growth with nitrate or arginine does not occur. Acid is not produced from lactose, glycerol, D-glucose, D-fructose, D-arabinose, maltose, D-xylose,

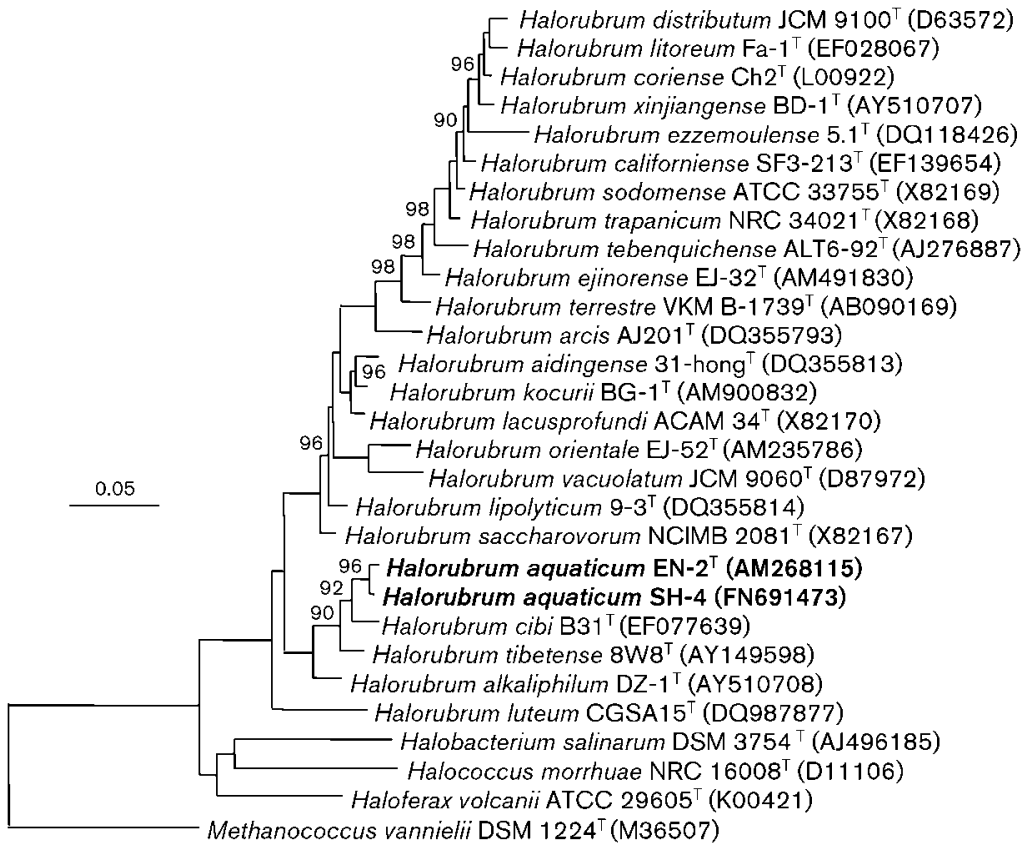

Fig. 1. Maximum-parsimony phylogenetic tree based on 16S rRNA gene sequence comparison showing the relationships between strains $\mathrm{EN}-2^{\top}$ and $\mathrm{SH}-4$ and members of the genus Halorubrum and other archaea. Bootstrap values $(>80 \%)$ based on 1000 replicates are shown at branch nodes. Bar, 5\% sequence divergence. 
D-galactose, trehalose or D-mannose. Growth occurs with glycerol, D-mannitol, D-fructose, lactose, maltose, sucrose, trehalose, D-glucose, D-arabinose, starch, L-glutamate and fumarate as single carbon and energy sources, but not with D-sorbitol, mannose, raffinose, D-ribose, D-xylose, succinate, propionate, malate or acetate. Growth occurs with glycine as a sole carbon, nitrogen and energy source, but not with L-asparagine, L-lysine, L-serine or L-threonine. Susceptible to ( $\mu \mathrm{g}$ per disc unless otherwise stated) novobiocin (30), bacitracin (10 U), erythromycin (15) and streptomycin (10) and resistant to rifampicin (5), ampicillin (10), neomycin (30), chloramphenicol (30) and nalidixic acid (30). The polar lipids are phosphatidylglycerol, phosphatidylglycerol phosphate methyl ester, sulfated diglycosyl diethers and several unidentified glycolipids. The DNA G $+\mathrm{C}$ content of the type strain is $62.1 \mathrm{~mol} \%\left(T_{\mathrm{m}}\right)$.

The type strain, EN-2 ${ }^{\mathrm{T}}\left(=\right.$ CECT $7174^{\mathrm{T}}=$ CGMCC $1.6377^{\mathrm{T}}$ $=\mathrm{JCM} 14031^{\mathrm{T}}$ ), was isolated from a saline lake, Lake Erliannor, in Inner Mongolia, China. Strain SH-4, from a similar source, is a second strain of the species.

\section{Acknowledgements}

This work was supported by grants from the Spanish Ministerio de Educación y Ciencia (grants no. BIO2009-10138 and CGL201019303), the National Science Foundation (grant no. DEB-0919290) and the Junta de Andalucía (grant no. P06-CVI-01829).

\section{References}

Arahal, D. R., Dewhirst, F. E., Paster, B. J., Volcani, B. E. \& Ventosa, A. (1996). Phylogenetic analyses of some extremely halophilic archaea isolated from Dead Sea water, determined on the basis of their $16 \mathrm{~S}$ rRNA sequences. Appl Environ Microbiol 62, 3779-3786.

Castillo, A. M., Gutiérrez, M. C., Kamekura, M., Xue, Y., Ma, Y., Cowan, D. A., Jones, B. E., Grant, W. D. \& Ventosa, A. (2006). Halorubrum orientale sp. nov., a halophilic archaeon isolated from Lake Ejinor, Inner Mongolia, China. Int J Syst Evol Microbiol 56, 2559-2563.

Castillo, A. M., Gutiérrez, M. C., Kamekura, M., Xue, Y., Ma, Y., Cowan, D. A., Jones, B. E., Grant, W. D. \& Ventosa, A. (2007). Halorubrum ejinorense sp. nov., isolated from Lake Ejinor, Inner Mongolia, China. Int J Syst Evol Microbiol 57, 2538-2542.

Chun, J., Lee, J.-H., Jung, Y., Kim, M., Kim, S., Kim, B. K. \& Lim, Y.-W. (2007). EzTaxon: a web-based tool for the identification of prokaryotes based on $16 \mathrm{~S}$ ribosomal RNA gene sequences. Int J Syst Evol Microbiol 57, 2259-2261.

Cui, H.-L., Tohty, D., Zhou, P.-J. \& Liu, S.-J. (2006). Halorubrum lipolyticum sp. nov. and Halorubrum aidingense sp. nov., isolated from two salt lakes in Xin-Jiang, China. Int J Syst Evol Microbiol 56, 16311634.

Cui, H.-L., Lin, Z.-Y., Dong, Y., Zhou, P.-J. \& Liu, S.-J. (2007). Halorubrum litoreum sp. nov., an extremely halophilic archaeon from a solar saltern. Int J Syst Evol Microbiol 57, 2204-2206.

Fan, H., Xue, Y., Ma, Y., Ventosa, A. \& Grant, W. D. (2004). Halorubrum tibetense sp. nov., a novel haloalkaliphilic archaeon from Lake Zabuye in Tibet, China. Int J Syst Evol Microbiol 54, 12131216.
Feng, J., Zhou, P.-J. \& Liu, S.-J. (2004). Halorubrum xinjiangense sp. nov., a novel halophile isolated from saline lakes in China. Int J Syst Evol Microbiol 54, 1789-1791.

Feng, J., Zhou, P., Zhou, Y.-G., Liu, S.-J. \& Warren-Rhodes, K. (2005). Halorubrum alkaliphilum sp. nov., a novel haloalkaliphile isolated from a soda lake in Xinjiang, China. Int J Syst Evol Microbiol 55, 149152.

Franzmann, P. D., Stackebrandt, E., Sanderson, K., Volkman, J. K., Cameron, D. E., Stevenson, P. L., McMeekin, T. A. \& Burton, H. R. (1988). Halobacterium lacusprofundi sp. nov., a halophilic bacterium isolated from Deep Lake, Antarctica. Syst Appl Microbiol 11, 20-27.

Grant, W. D., Kamekura, M., McGenity, T. J. \& Ventosa, A. (2001). Order I. Halobacteriales Grant \& Larsen 1989b, 495 ${ }^{\mathrm{VP}}$ (Effective publication: Grant \& Larsen 1989a, 2216). In Bergey's Manual of Systematic Bacteriology, 2nd edn, vol. 1, pp. 294-334. Edited by D. R. Boone, R. W. Castenholz \& G. M. Garrity. New York: Springer.

Gutiérrez, M. C., Kamekura, M., Holmes, M. L., Dyall-Smith, M. L. \& Ventosa, A. (2002). Taxonomic characterization of Haloferax sp. (" $H$. alicantei") strain Aa 2.2: description of Haloferax lucentensis sp. nov. Extremophiles 6, 479-483.

Gutiérrez, M. C., Castillo, A. M., Pagaling, E., Heaphy, S., Kamekura, M., Xue, Y., Ma, Y., Cowan, D. A., Jones, B. E. \& other authors (2008). Halorubrum kocurii sp. nov., an archaeon isolated from a saline lake. Int J Syst Evol Microbiol 58, 2031-2035.

Hu, L., Pan, H., Xue, Y., Ventosa, A., Cowan, D. A., Jones, B. E., Grant, W. D. \& Ma, Y. (2008). Halorubrum luteum sp. nov., isolated from Lake Chagannor, Inner Mongolia, China. Int J Syst Evol Microbiol 58, 1705-1708.

Johnson, J. L. (1994). Similarity analysis of DNAs. In Methods for General and Molecular Bacteriology, pp. 655-681. Edited by P. Gerhardt, R. G. E. Murray, W. A. Wood \& N. R. Krieg. Washington, DC: American Society for Microbiology.

Kamekura, M. (1993). Lipids of extreme halophiles. In The Biology of Halophilic Bacteria, pp. 135-161. Edited by R. H. Vreeland \& L. I. Hochstein. Boca Raton, FL: CRC Press.

Kamekura, M. \& Dyall-Smith, M. L. (1995). Taxonomy of the family Halobacteriaceae and the description of two new genera Halorubrobacterium and Natrialba. J Gen Appl Microbiol 41, 333-350.

Kamekura, M., Dyall-Smith, M. L., Upasani, V., Ventosa, A. \& Kates, M. (1997). Diversity of alkaliphilic halobacteria: proposals for transfer of Natronobacterium vacuolatum, Natronobacterium magadii, and Natronobacterium pharaonis to Halorubrum, Natrialba, and Natronomonas gen. nov., respectively, as Halorubrum vacuolatum comb. nov., Natrialba magadii comb. nov., and Natronomonas pharaonis comb. nov., respectively. Int J Syst Bacteriol 47, 853-857.

Kharroub, K., Quesada, T., Ferrer, R., Fuentes, S., Aguilera, M., Boulahrouf, A., Ramos-Cormenzana, A. \& Monteoliva-Sánchez, M. (2006). Halorubrum ezzemoulense sp. nov., a halophilic archaeon isolated from Ezzemoul sabkha, Algeria. Int J Syst Evol Microbiol 56, 1583-1588.

Lizama, C., Monteoliva-Sánchez, M., Suárez-García, A., RosellóMora, R., Aguilera, M., Campos, V. \& Ramos-Cormenzana, A. (2002). Halorubrum tebenquichense sp. nov., a novel halophilic archaeon isolated from the Atacama Saltern, Chile. Int J Syst Evol Microbiol 52, 149-155.

López-García, P., Moreira, D., López-López, A. \& Rodríguez-Valera, F. (2001). A novel haloarchaeal-related lineage is widely distributed in deep oceanic regions. Environ Microbiol 3, 72-78.

Ludwig, W., Strunk, O., Klugbauer, S., Klugbauer, N., Weizenegger, M., Neumaier, J., Bachleitner, M. \& Schleifer, K.-H. (1998). Bacterial phylogeny based on comparative sequence analysis. Electrophoresis 19, 554-568. 
Ludwig, W., Strunk, O., Westram, R., Richter, L., Meier, H., Yadhukumar, Buchner, A., Lai, T., Steppi, S. \& other authors (2004). ARB: a software environment for sequence data. Nucleic Acids Res 32, 1363-1371.

Marmur, J. (1961). A procedure for the isolation of deoxyribonucleic acid from micro-organisms. J Mol Biol 3, 208-218.

Marmur, J. \& Doty, P. (1962). Determination of the base composition of deoxyribonucleic acid from its thermal denaturation temperature. J Mol Biol 5, 109-118.

McGenity, T. J. \& Grant, W. D. (1995). Transfer of Halobacterium saccharovorum, Halobacterium sodomense, Halobacterium trapanicum NRC 34021 and Halobacterium lacusprofundi to the genus Halorubrum gen. nov., as Halorubrum saccharovorum comb. nov., Halorubrum sodomense comb. nov., Halorubrum trapanicum comb. nov., and Halorubrum lacusprofundi comb. nov. Syst Appl Microbiol 18, 237-243.

McGenity, T. J. \& Grant, W. D. (2001). Genus VII. Halorubrum. In Bergey's Manual of Systematic Bacteriology, 2nd edn, vol. 1, pp. 320324. Edited by D. R. Boone, R. W. Castenholz \& G. M. Garrity. New York: Springer.

Oren, A. (1983). Halorubrum sodomense sp. nov., a Dead Sea halobacterium with an extremely high magnesium requirement. Int J Syst Bacteriol 33, 381-386.

Oren, A. (1994). The ecology of the extremely halophilic archaea. FEMS Microbiol Rev 13, 415-439.

Oren, A. \& Ventosa, A. (1996). A proposal for the transfer of Halorubrobacterium distributum and Halorubrobacterium coriense to the genus Halorubrum as Halorubrum distributum comb. nov. and Halorubrum coriense comb. nov., respectively. Int J Syst Bacteriol 46, 1180.

Oren, A., Ventosa, A. \& Grant, W. D. (1997). Proposed minimal standards for description of new taxa in the order Halobacteriales. Int J Syst Bacteriol 47, 233-238.

Oren, A., Arahal, D. R. \& Ventosa, A. (2009). Emended descriptions of genera of the family Halobacteriaceae. Int J Syst Evol Microbiol 59, 637-642.

Owen, R. J. \& Hill, L. R. (1979). The estimation of base compositions, base pairing and genome size of bacterial deoxyribonucleic acids. In Identification Methods for Microbiologists, 2nd edn, pp. 217-296. Edited by F. A. Skinner \& D. W. Lovelock. London: Academic Press.
Pesenti, P. T., Sikaroodi, M., Gillevet, P. M., Sánchez-Porro, C., Ventosa, A. \& Litchfield, C. D. (2008). Halorubrum californiense sp. nov., an extreme archaeal halophile isolated from a crystallizer pond at a solar salt plant in California, USA. Int J Syst Evol Microbiol 58, 2710-2715.

Petter, H. F. M. (1931). On bacteria of salted fish. Proc K Ned Akad Wet Amsterdam 34, 1417-1423.

Roh, S. W. \& Bae, J.-W. (2009). Halorubrum cibi sp. nov., an extremely halophilic archaeon from salt-fermented seafood. J Microbiol 47, 162166.

Saitou, N. \& Nei, M. (1987). The neighbor-joining method: a new method for reconstructing phylogenetic trees. Mol Biol Evol 4, 406425.

Stackebrandt, E. \& Goebel, B. M. (1994). Taxonomic note: a place for DNA-DNA reassociation and $16 \mathrm{~S}$ rRNA sequence analysis in the present species definition in bacteriology. Int J Syst Bacteriol 44, 846849.

Stackebrandt, E., Frederiksen, W., Garrity, G. M., Grimont, P. A. D., Kämpfer, P., Maiden, M. C. J., Nesme, X., Rosselló-Mora, R., Swings, J. $\&$ other authors (2002). Report of the ad hoc committee for the reevaluation of the species definition in bacteriology. Int J Syst Evol Microbiol 52, 1043-1047.

Tomlinson, G. A. \& Hochstein, L. I. (1976). Halobacterium saccharovorum sp. nov., a carbohydrate-metabolizing, extremely halophilic bacterium. Can J Microbiol 22, 587-591.

Ventosa, A., Gutiérrez, M. C., Kamekura, M., Zvyagintseva, I. S. \& Oren, A. (2004). Taxonomic study of Halorubrum distributum and proposal of Halorubrum terrestre sp. nov. Int J Syst Evol Microbiol 54, 389-392.

Wayne, L. G., Brenner, D. J., Colwell, R. R., Grimont, P. A. D., Kandler, O., Krichevsky, M. I., Moore, L. H., Moore, W. E. C., Murray, R. G. E. \& other authors (1987). International Commitee on Systematic Bacteriology. Report of the ad hoc committee on reconciliation of approaches to bacterial systematics. Int J Syst Bacteriol 37, 463-464.

Xu, X.-W., Wu, Y.-H., Zhang, H. B. \& Wu, M. (2007). Halorubrum arcis sp. nov., an extremely halophilic archaeon isolated from a saline lake on the Qinghai-Tibet Plateau, China. Int J Syst Evol Microbiol 57, 1069-1072. 